\title{
PENINGKATAN KUALITAS HIDUP PASIEN HEMODIALISA DITINJAU DARI PERILAKU CARING PERAWAT DI RSUD dr. SOETOMO SURABAYA
}

\author{
Nikmatul Fadilah, Dyah Wijayanti, Tumini \\ Prodi DIII Keperawatan Kampus Sutopo Surabaya \\ Poltekkes Kemenkes Surabaya
}

\begin{abstract}
Patients with chronic renal failure who undergoing hemodialysis decreased vitality, physical and psychological function that caused of decreased quality of life. The effect of caring to patient are improved relations of mutual trust, increase physical healing andsafety, have more energy, lower maintenance costs and create more comfortable feeling. The purpose of this study was to analyze the relationship between caring behaviors with quality of life. This study was analytic cross sectional. The sample was 60 patients in Hemodialysis Unit RSU Dr.Soetomo Surabaya, that was taken by purposive sampling. Independent variable wascaring behaviors, and dependent variable wasquality of life. Data were collected using 25-Caring Dimension Inventory (CDI 25) questionnaire and modifications Kidney Dissease Quality of Life Short Form. Data were analysis using Spearman's Rho test with $\alpha$ 0.05. The results showed that a good caring behavior (48.3\%) and excellent (51.7\%). The quality of life was moderate (83.3\%). Spearman's rho test showed that the caring behavior did not significantly influence the quality of life with $p$ value 0.229 . The achievement of good judgment by patients need to be maintained and enhanced so that it will create a positive image of nurses from the public. Quality of life who have reached the moderate level needs to be improved, with a joint effort between the patient, family, and health workers. Improved quality of life, especially physical and psychological dimensions so that the patient will achieve adaptive coping strategies, while supported by families and health workers, especially nurses as part of the environmental and social dimensions of the patient.
\end{abstract}

Keyword: hemodialysis, caring, quality of life.

\section{PENDAHULUAN}

Gagal ginjal adalah suatu keadaan klinis yang ditandai dengan penurunan fungsi ginjal yang bersifat ireversibel, dengan penurunan GFR hingga $<15 \mathrm{~mL} / \mathrm{min} / 1,73 \mathrm{~m}^{2}$, yang memerlukan renal replacement therapy (RRT) berupa dialisis atau transplantasi ginjal (Suwitra, 2006). Gagal ginjal kronik membutuhkan terapi pengganti ginjal permanen berupa dialisis (hemodialisa dan peritoneal dialisis) atau transplantasi ginjal (Utami, 2011). Terapi hemodialisa yang dijalani penderita gagal ginjal tidak mampu mengimbangi hilangnya aktivitas metabolik atau endokrin yang dilaksanakan ginjal akan berpengaruh terhadap kualitas hidup pasien.

Tahun 2009 di Amerika diperkirakan terdapat penderita gagal ginjal kronik sebanyak 116.395 orang dan lebih dari 380.000 orang penderita gagal ginjal kronik mendapatkan terapi hemodialisa regular (USRDS, 2011). Di Indonesia terdapat 15.353 pasien yang baru menjalani hemodialisa dan pada tahun 2012 terjadi peningkatan pasien hemodialisa menjadi 19.621 orang (Indonesian Renal Registry, 2013). Hasil penelitian Ibrahim (2009) menunjukkan bahwa $57,2 \%$ pasien yang menjalani hemodialisa mempersepsikan kualitas hidupnya pada tingkat rendah dan $42,9 \%$ pada tingkat tinggi.

Gaya hidup yang terencana berhubungan dengan terapi hemodialisa (2-3 kali seminggu selama $3-4$ jam) dan pembatasan asupan cairan menghilangkan semangat hidup pasien, hal ini akan mempengaruhi kualitas hidup pasien gagal ginjal kronis (Brunner \& Suddarth, 2001). Penilaian kualitas hidup pada pasien hemodialisa menjadi tujuan penting dalam pengobatan penyakit ginjal tahap akhir, karena berhubungan dengan morbiditas dan mortalitas pasien gagal ginjal. Pasien hemodialisa dengan kualitas hidup yang rendah akan meningkatkan 
mortalitas dibandingkan dengan populasi normal (Zadeh, 2003).

Caring sebagai fokus utama dalam bidang keperawatan yang akan memberi dampak bagi pasien berupa peningkatkan hubungan saling percaya, meningkatkan penyembuhan fisik, keamanan, memiliki banyak energi, biaya perawatan lebih rendah, serta menimbulkan perasaan lebih nyaman (Swanson, 1999 dalam Watson 2004). Perilaku caring adalah pengetahuan, sikap dan keterampilan seorang tenaga perawat dalam merawat pasien dan keluarga dengan memberikan dorongan positif, dukungan dan peningkatan pelayanan perawatan. Perawat dapat memberi dukungan kepada pasien gagal ginjal kronis dengan mengidentifikasi strategi koping yang efektif dan aman untuk menghadapi masalah dan rasa takut sehingga kualitas hidup pasien gagal ginjal kronis dapat meningkat (Pryzby, 2004; Smeltzer dan Bare, 2004). Perawat unit hemodialisis harus mempunyai kemampuan profesional dalam mempersiapkan pasien sebelum hemodialisis, memantau kondisi pasien selama hemodialisis dan berkolaborasi dalam melakukan evaluasi pencapaian adekuasi sehingga dapat meningkatkan kualitas hidup pasien hemodialisis (Botton, 1998; Braun, 2008; Compton, 2002).

\author{
METODE \\ Desain Penelitian \\ Desain penelitian ini adalah analitik dengan \\ pendekatan cross sectional.
}

\section{Sampel dan Sampling}

Sampel penelitian ini adalah 70 pasien hemodialisa yang berobatdi poli hemodialisa RSUD dr. Soetomo Surabaya, dengan menggunakan purposif sampling.

\section{Instrumen Penelitian}

Instrumen yang digunakan adalah 25-Caring Dimension Inventory (CDI 25) Jean Watson untuk mengukur perilaku caring perawat dan Kidney Dissease Quality of Life Short Formyang dimodifikasi untuk mengukur kualitas hidup pasien.

\section{Analisis Data \\ Analisis statistik untuk mengukur pengaruh perilaku caring perawat dan kualitas hidup pasien hemodialisa menggunakan uji spearman's rho dengan $\mathrm{p}<0,05$.}

\section{HASIL DAN PEMBAHASAN \\ Perilaku Caring Perawat}

Tabel 1. Perilaku Caring Perawat Ruang Hemodialisa RSUD Dr. Soetomo Surabaya tahun 2015

\begin{tabular}{lcc}
\hline \multicolumn{1}{c}{ Perilaku caring } & N & \% \\
\hline Sangat baik & 31 & 51,7 \\
Baik & 29 & 48,3 \\
Cukup & 0 & 0 \\
Kurang & 0 & 0 \\
Total & 60 & 100 \\
\hline
\end{tabular}

Data tabel 1 menunjukkan seluruh perawat telah mencapai perilaku profesional yaitu perilaku caring dalam kategori baik $(48,3 \%)$ dan sangat baik $(51,7 \%)$. Perawat di ruang hemodialisa RSUD Dr Soetomo Surabaya mampu mencapai performa terbaik yang menjadi fokus utama keperawatan dalam melaksanakan asuhan perawatan pada pasien hemodialisa.

Seluruh perawat ruang Hemodialisa RSUD Dr. Soetomo Surabaya telah mencapai perilaku profesional yaitu perilaku caring dalam kategori baik $(48,3 \%)$ dan sangat baik $(51,7 \%)$. Caringsebagai fokus utama dalam bidang keperawatan yang akan memberi dampak bagi pasien berupa peningkatkan hubungan saling percaya, meningkatkan penyembuhan fisik, keamanan, memiliki banyak energi, biaya perawatan lebih rendah, serta menimbulkan perasaan lebih nyaman (Swanson, 1999 dalam Watson 2004). Perilaku caring adalah pengetahuan, sikap dan keterampilan seorang tenaga perawat dalam merawat pasien dan keluarga dengan memberikan dorongan positif, dukungan dan peningkatan pelayanan perawatan.

Perawat di ruang hemodialisa RSUD Dr Soetomo Surabaya mampu mencapai 
performa terbaik yang menjadi fokus utama keperawatan dalam melaksanakan asuhan perawatan pada pasien hemodialisa. Tingginya penilaian perilaku caring perawat oleh pasien hemodialisa dalam penelitian ini merupakan suatu keadaan positif yang dapat memicu peningkatan kulaitas pelayanan di ruang hemodialisa RSUD Dr. Soetomo Surabaya. Penilaian positif dari pasien merupakan suatu penghargaan dan pencapaian yang baik ini perlu dipertahankan dan ditingkatkan agar dapat menciptakan citra yang baik terhadap perawat di masyarakat secara umum. Tercapainya performa perilaku caring perawat di ruang hemodialisa ini dapat didukung oleh pengetahuan perawat. Perawat yang bertugas di ruang hemodialisa RSUD Dr. Soetomo dengan pendidikan diploma III keperawatan dan beberapa telah menyelesaikan pendidikan profesi ners merupakan salah satu latar belakang tercapainya pemahaman yang baik tentang perilaku caring dan ditunjukkan dengan sikap yang sesuai dengan konsep caring perawat (Koswara, 2002). Pencapain prestasi rumah sakit Dr. Soetomo Surabaya yaitu lulus akreditasi KARS 2012 mendukung dan merupakan indikator telah baiknya kualitas SDM rumah sakit termasuk perawat.

Perilaku caring perawat di ruang hemodialisa RSUD Dr. Soetomo Surabaya yang dinilai tinggi oleh pasien penyakit ginjal kronik yang menjalani hemodialisa merupakan gambaran dari pengalaman pasien yang cukup lama terhadap pelayanan yang mereka terima selama menjalani terapi hemodialisa rutin seminggu 2 kali. Kesan yang diekspresikan pasien selama menjalani perawatan akan meningkatkan kepuasan pasien akan pelayanan perawat dan dapat membantu pasien meningkatkan kesejahterannya sebagaimana penelitian Abdul, dkk (2013) di rumah sakit umum kota Baubau.

Interaksi dan komunikasi terapeutik yang terus menerus antara pasien dan perawat di ruang hemodialisa disertai dengan pengalaman positif akan pelayanan yang diterima akan menimbulkan perasaan nyaman pasien dan terus mewujudkan citra pelayanan keperawatan yang baik sebagaimana harapan dan tuntutan masyarakat.

\section{Kualitas Hidup Pasien Hemodialisa}

Tabel 2. Kualitas Hidup Pasien Hemodialisa RSUD Dr. Soetomo Surabaya tahun 2015

\begin{tabular}{lcc}
\hline \multicolumn{1}{c}{ Kualitas Hidup } & N & \% \\
\hline Rendah & 4 & 6,7 \\
Sedang & 50 & 83,3 \\
Baik & 6 & 10 \\
Total & 60 & 100 \\
\hline
\end{tabular}

Pasien penyakit ginjal kronik yang menjalani hemodialisa di RSUD Dr. Soetomo Surabaya sebagian besar $(83,3 \%)$ telah mencapai kualitas hidup sedang. Pasien hemodialisa mempersepsikan kesehatan fisik, psikologis, tingkat kebebasan, hubungan sosial, dan lingkungan mereka pada kondisi sedang.

Pasien penyakit ginjal kronik yang menjalani hemodialisa di RSUD Dr. Soetomo Surabaya sebagian besar $(83,3 \%)$ telah mencapai kualitas hidup sedang. Kualitas hidup adalah kondisi dimana pasien kendati penyakit yang dideritanya dapat tetap merasa nyaman secara fisik, psikologis, sosial maupun spiritual serta secara optimal memanfaatkan hidupnya untuk kebahagian dirinya maupun orang lain. Kualitas hidup tidak terkait dengan lamanya seorang akan hidup karena bukan domain manusia untuk menentukannya (Suhud, 2009).

Kualitas hidup ditetapkan sebagai suatu persepsi individual dari posisi seseorang dalam kehidupan yang mempunyai budaya dan sistem nilai dimana orang itu tinggal, berkaitan dengan tujuan, harapan standar dan perhatian.Persepsi tersebut meliputi kesehatan fisik seseorang, psikologis, tingkat kebebasan, hubungan sosial, dan hubungan mereka dengan lingkungan. Disamping kondisi penyakit dan terapi yang harus dijalani, beberapa faktor dapat mempengaruhi kualitas hidup diantaranya faktor demografi yang meliputi usia; jenis kelamin; pendidikan; status pernikahan, status ekonomi/asuransi, faktor hubungan sosial keluarga/dukungan keluarga, serta faktor 
mental spiritual individu/koping individu (Handayani, 2013; Desnauli 2011; Santoso, 2010; Slamet, 2014).

Penilaian kualitas hidup pada pasien penyakit ginjal kronik dapat menggunakan instrumen Kidney Disease Quality of Life Short Form (KDQOL-SF). Instrumen ini menilai kualitas hidup berdasarkan 11 komponen yaitu gejala yang dirasakan, efek penyakit ginjal, beban akibat penyakit ginjal, status pekerjaan, fungsi kognitif, kualitas interaksi sosial, fungsi sexual, pemenuhan kebutuhan tidur, dukungan social (keluarga/tetangga/kerabat/teman), dukungan petugas dialysis, kepuasan pasien (Hays et al, 1995). Pasien yang menjalani hemodialisa di RSUD Dr Soetomo Surabaya sebagian besar berada pada kualitas hidup yang sedang. Berdasarkan sebelas komponen kualitas hidup pada KDQoL, sebagian besar pasien berada pada penilaian yang rendah pada 5 komponen yaitu gejala yang dirasakan, efek penyakit ginjal, beban akibat penyakit ginjal, status pekerjaan, dan pemenuhan kebutuhan tidur. Enam komponen yang berada pada kondisi maksimal atau nilai maksimal yang dirasakan sebagian besar responden yaitu fungsi kognitif, kualitas interaksi sosial, fungsi sexual, dukungan sosial, dukungan petugas dialysis, kepuasan pasien.

Dua gejala tersering yang dirasakan pasien hemodialisa adalah rasa nyeri/kram terutama ektremitas, dan pusing. Nyeri otot atau kram merupakan kondisi pada kasus ginjal kronik akibat terganggunya fungsi pengaturan keseimbangan elektorlit dalam tubuh terutama otot. Pusing atau nyeri kepala yang dirasakan 71,7\% pasien dilatarbelakangi oleh kasus penyebab gangguan ginjal kronik yaitu hipertensi. Literature review oleh Panthee \& kriptacha (2011) menyebutkan bahwa kecemasan tigkat tingi dalam beberapa bulan pada pasien infark miokard mempengaruhi kualitas hidup pasien. Studi ini menyatakan beberapa jurnal menyatakan bahwa kecemasan berkaitan dengan komplikasi penyakit, dan seluruh jurnal mengatakan bahwa kecemasan tingkat tinggi menyebabkan penurunan kualitas hidup pasien sampai level rendah. Gejala penyakit yang dirasakan pasien hemodialisa ini akan berpengaruh negatif pada nilai kualitas hidupnya.

Sebagian besar responden menyatakan
bahwa penyakit yang dideritanya
mempengaruhi/berefek terhadap aktivitas fisik
rutin/pekerjaannya sehingga timbul perasaan bahwa dirinya menjadi beban bagi keluarga. Persaan tidak sempurna, mudah lelah, kondisi tidak seperti orang lain yang sehat, serta penurunan aktivitas fisik/kemampuan bekerja seperti sebelum sakit ditunjukkan dengan kondisi pasien yang sebagian besar $(60 \%)$ sudah tidak lagi bekerja. Selain itu sebagian besar pasien $(60 \%)$ yang berada pada kelompok usia dewasa namun tidak mampu lagi bekerja memperkuat timbulnya perasaan lemah dan membebani. Kondisi tersebut senada dengan penelitian yang dilakukan oleh Hanafi (2010) bahwa kemampuan bekerja/status pekerjaan mempengaruhi kualitas hidup pasien.

Melemahnya kondisi fisik dan gejala yang dirasakan menganggu dalam pemenuhan kebutuhan tidur pasien sebesar 58,3\% sebagai salah satu indikator belum maksimalnya kualitas hidup pasien penyakit ginjal kronik. Masih lemahnya koping individu yang ditunjukkan dengan sikap merasa tidak sempurna, lemah, dan membebani akan menurunkan kualitas hidup pasien sebagaimana kajian Desnauli, dkk (2011) yang menyatakan bahwa koping individu yang adaptif pada pasien gagal ginjal kronis akan berpengaruh positif terhadap kualitas hidupnya. Kemampuan koping pasien penyakit ginjal kronik pada dimensi fisik dan psikologis merupakan hal penting yang harus diperhatikan petugas termasuk perawat sehingga mereka dapat mencapai kualitas hidup yang lebih baik.

Beban secara finansial yaitu biaya perawatan sebagaimana disampaikan responden pada penelitian ini sangat terbantu degan keikutsertaan mereka dalam program jaminan kesehatan yang ada baik berupa bpjs perorangan atau pegawai negeri sipil/pensiunan, maupun jamkesmas/program maskin. Situasi ini sesuai dengan kajian yang disampaikan oleh Winiarti (2012) bahwa implemenatsi kebijakan kesehatan khususnya asuransi kesehatan yang terintegrasi dengan strategi kesehatan nasional sangatlah penting sehingga masyarakat dapat mencapai derajat kesehatan yang terbaik dan pemerintah dapat mencapai health outcome sesuai tujuan nasional.

Indikator yang masih menunjukkan nilai positif atau tidak ada gangguan yang disampaikan sebagian besar pasein hemodialisa yaitu kemampuan menangkap pembicaraan orang lain dan masih merasa mudah berkonsentrasi, tidak mudah bereaksi marah, rukun dengan siapa saja, merasa masih mampu melakukan interaksi sosial/berkumpul dengan 
keluarga/teman/tetangga, serta tidak merasakan masalah seksual. Komponen dukungan sosial dari keluarga/teman/tetangga serta dukungan petugas kesehatan hampir seluruhnya menyampaikan positif. Respon pasien terhadap kepuasan akan pelayanan petugas dialysis baik berupa dukungan untuk beradaptasi dan dorongan untuk hidup mandiri hampir seluruh pasien menilai baik. Sebagaimana hasil penelitian Handayani, dkk (2013) dan
Rahmawati, dkk (2014) bahwa dukungan keluarga akan meningkatkan kualitas hidup pasien penyakit kronik yaitu penyakit ginjal kronik dan diabetes mellitus tipe 2. Dukungan keluarga dan petugas kesehatan akan memberikan makna positif terhadap peningkatan kualitas hidup pasien.

Peningkatan Kualitas Hidup Ditinjau dari Perilaku Caring Perawat

\section{Tabel 3. Tabulasi Silang Perilaku Caring Perawat dan Kualitas Hidup Pasien Hemodialisa RSUD Dr. Soetomo Surabaya Tahun 2015}

\begin{tabular}{lcccc}
\hline \multirow{2}{*}{ Perilaku caring } & Rendah & Sedang & Baik & Total \\
\hline Baik & $4(13,8 \%)$ & $22(75,9 \%)$ & $3(10,3 \%)$ & $29(100 \%)$ \\
Sangat baik & 0 & $28(90,3 \%)$ & $3(9,7 \%)$ & $31(100 \%)$ \\
P value $=0,229$ & $\alpha=0,05$ & & & \\
\hline
\end{tabular}

Tabulasi silang data perilaku caring perawat dan kualitas hidup pasien hemodialisa menunjukkan bahwa perilaku caring perawat yang baik menujukkan kualitas hidup yang sedang $(75,9 \%)$ dan perilaku caring perawat sangat baik menunjukkan lebih banyak pencapaian kualitas hidup pasien kategori sedang sebesar $90,3 \%$. Perilaku caring perawat baik maupun sangat baik mampu menunjukkan kualitas hidup baik pada frekuensi yang sama yaitu masing-masing 3 responden. Hasil uji spearman's rho menunjukkan bahwa perilaku caring perawat tidak berpengaruh signifikan terhadap kulitas hidup pasien dengan $\mathrm{p}$ value 0,229 dengan $\alpha=0,05$.

Data perilaku caring perawat dan kualitas hidup pasien hemodialisa pada tabel 3 menunjukkan bahwa perilaku caring perawat yang baik menujukkan kualitas hidup yang sedang $(75,9 \%)$ dan perilaku caring perawat sangat baik menunjukkan lebih banyak pencapaian kualitas hidup pasien kategori sedang sebesar $90,3 \%$. Perilaku caring perawat baik maupun sangat baik mampu menunjukkan kualitas hidup baik pada frekuensi yang sama yaitu masing-masing 3 responden, dan penilaian statistik menunjukkan perilaku caring perawat tidak berpengaruh signifikan terhadap kulitas hidup pasien.

Kondisi pasien pada penelitian ini berbeda dengan asumsi dasar teori Watson menyebutkan bahwa caring yang efektif akanmeningkatkan status kesehatan dan perkembangan individu dan keluarga.
Penelitian Abdul, dkk (2013) dan Hidayati, dkk (2013) menyimpulkan bahwa periaku caring perawat signifikan meningkatkan kepuasan dan menurunkan kecemasan pasien, serta penelitian Handayani, dkk (2013) bahwa kualitas hidup pasien hemodialisa dapat meningkat dengan adanya dukungan keluarga. Nilai positif yang ditunjukkan pada komponen dukungan keluarga dan petugas kesehatan tidak mampu memberi makna secara signifikan pada perbaikan kualitas hidup pasien penyakit ginjal kronik yang menjalani hemodialisa.

Faktor internal yang ditunjukkan oleh gejala penyakit yang dirasakan, dampak terhadap kemampuan fisik, serta respon emosi yang masih lemah, perasaan membebani dan belum mencapai koping yang adaptif lebih berpengaruh signifikan terhadap keseluruhan penialaian kualitas hidup pasien hemodialisa. Kajian Desnauli, dkk (2013) menunjukkan betapa pentingnya pencapaian koping adaptif pasien hemodialisa sehingga mereka dapat mencapai kualitas hidup yang terbaik.

Kemampuan pasien hemodialisa mencapai strategi koping yang adaptif merupakan bagian penting peran perawat sebagaimana item 7, 10, 13 pada indicator perilaku caring yaitu memantau perkembangan kondisi selama terapi, mendampingi selama prosedur klinik/hemodialisa, serta mendengarkan keluhan pasien. Perawat dapat lebih banyak menghabiskan waktu dengan pasien sehingga dengan hal itu pasien akan dapat meningkatkan kualitas hidupnya. Peran 
penting perawat adalah perawat dapat mengidentifikasi area rejimen pengobatan yang dapat mempengaruhi kualitas hidup pasien dan mengembangkan strategi untuk mengurangi kualitas hidup yang negatif (Tallis, 2005). Perawat dapat memberi dukungan kepada pasien gagal ginjal kronis dengan mengidentifikasi strategi koping yang efektif dan aman untuk menghadapi masalah dan rasa takut sehingga kualitas hidup pasien gagal ginjal kronis dapat meningkat (Pryzby, 2004; Smeltzer dan Bare, 2004). Perawat unit hemodialisis harus mempunyai kemampuan profesional dalam mempersiapkan pasien sebelum hemodialisis, memantau kondisi pasien selama hemodialisis dan berkolaborasi dalam melakukan evaluasi pencapaian adekuasi sehingga dapat meningkatkan kualitas hidup pasien hemodialisis (Botton, 1998; Braun, 2008; Compton, 2002).

\section{KESIMPULAN DAN REKOMENDASI \\ Kesimpulan}

1. Perawat di ruang hemodialisa RSUD Dr. Soetomo Surabaya menunjukkan perilaku caring baik dan sangat baik

2. Sebagain besar pasein hemodialisa di RSUD Dr. Soetomo Surabaya mencapai kulitas hidup sedang

3. Perilaku caring perawat tidak memberi makna secara signifikan pada peningkatkan kualitas hidup pasien hemodialisa di RSUD Dr. Soetomo Surabaya.

\section{Rekomendasi}

1. Pencapaian penilaian yan baik oleh pasien terhadap perawat di ruang hemodialisa RSUD Dr. Soetomo Surabaya perlu terus dipertahankan dan ditingkatkan sehingga akan menciptakan citra positif perawat dari masyarakat secara umum

2. Kualitas hidup pasien hemodialisa yang telah mencapai level sedang perlu ditingkatkan, dengan upaya bersama antara pasien, keluarga, dan petugas. Perbaikan kualitas hidup terutama pada dimensi fisik dan psikologis sehingga pasien akan mencapai strategi koping yang adaptif, dengan tetap didukung oleh keluarga dan petugas kesehatan khususnya perawat sebagai bagian dimensi lingkungan dan social pasien.

\section{DAFTAR PUSTAKA}

Brunner and Suddarth (2001). Keperawatan Medikal Bedah. Edisi b Volume 2. Jakarta: Penerbit Buku Kedokteran EGC.

Clearly, J., Drennan, J. (2005). Quality of Life of Patients on Haemodialysis for End-Stage Renal Disease.Journal of Advanced Nursing. 2005; 51(6) : 571 586.

Dwidiyanti. (2007). Caring: Kunci Sukses Perawat/Ners Mengamalkan Ilmu. Semarang: Penerbit Hasani.

Farida, A. (2010). Pengalaman Klien Hemodialisis Terhadap Kualitas Hidup Dalam Konteks Asuhan Keperawatan Di RSUP Fatmawati Jakarta. Tesis. Diakses tanggal 17 Januari 2015. Website http://lib.ui.ac.id/file?file=digital/137288 -T-Anna\%20Farida.pdf.

Hays, R.D., Kallich, J.D., Mapes, D.L.Coons, S.J.,Amin,N \& Carter,W.B. (1995). Kidney Disease Quality of Life Short Form (KDQOL-SF $\left.{ }^{T M}\right)$, Version 1.3: A Manual for Use and Scoring. Santa Monica, CA: RAND, P-7994.

Indonesian Renal Registry. (2013). Report of Indonesian Renal Registry.

Kaltara. (2009). Membangun Pribadi Caring Perawat. Diakses tanggal 20 Januari 2015. Website http://akperkaltara. ac. id/index.php.

Lewis et al. (1998). Medical Surgical Nursing; Assesment and Management of Clinical Problem $\left(5^{\text {th }} e d\right)$, California: AddisonWesly.

Lumenta, Nico, A, dkk. (1992). Penyakit Ginjal. Penerbit PT. BPK Gunung Mulia.

Muhlisin, A., Ichsan, B. (2008). Aplikasi Model Konseptual Caring Dari Jean Watson Dalam Asuhan Keperawatan. Berita Ilmu Keperawatan ISSN 1979-2697, Vol. 1No.3, September 2008: 147-150. Diakses tanggal 26 Januari 2015. Website http://publikasiilmiah. ums.ac. id/bitstream/handle.

Pryzby. (2004). Effect of Nurse Caring Behaviours on family stress responses in critical care. Journal of Intensive and Critical Care Nursing, 21, 16-23. Florida: Elsevier.

Septiwi, C. (2010). Hubungan antara adekuasi hemodialysis dengan kualitas hidup pasien hemodialysis di unit hemodialysis RS. Prof. Dr. Margono Soekarjo Purwokerto. Tesis. Diakses tanggal 19 
Januasi 2015. Website http://lib. ui.ac. id/filedf.

Smeltzer, C. Suzanne, dkk. (2001). Buku Ajar Keperawatan Medikal Bedah. Edisi 8. Jakarta. EGC.

Smeltzer dan Bare. (2004). Buku Ajar Keperawatan Medikal Bedah. Jakarta: EGC.

Suryani. (2010). Modifikasi dari Caring Behaviour Assesment Tools (Cronin \& Harrison, 1988).

Swanson. (1991). A deconstruction of caring. Journal of Advanced Nursing. Vol 8, 1554-1558.

Tallis, K. (2005). How to Improve The Quality of Life in Patients Living With End Stage Renal Failure. Renal Nursing Society of Australian Journal, Vol. 1. No.1.

USRDS. (2013). Incidence, Prevalence, Patient Characteristics and Treatment Modalities, Vol. 2, USA. Diakses tanggal
16 Januari 2015. Website http://usrds. go.org.

USRDS. (2013). Chronic Kidney Disease in The General Population. Vol.1. USA. Diakses tanggal 16 Januari 2015. Website http://usrds.go.org.

Villaverde, M., et al. (2005). Interdialytic Weight Gain as A Marker of Blood Pressure, Nutrition and Survival in Hemodialysis Patients. Diakses tanggal 21 Januari 2015. Website http://proquest.umi.com.

Watson. (2004). Theory of Human Caring. Diakses tanggal 19 Januari 2015. Website http://www2.uchsc.edu/son/ caring.

Zadeh, K.K., Koople, J.D., Block, G. (2001). Association among SF-36 Quality of Life Measures and Nutrition, Hospitalization and Mortality in Hemodialysis. Diakses tanggal 18 Januari 2015. Website http://www. asnjournals.org 